
WATER RESOURCES DIVISION, MASSACHUSETTS AND RHODE ISLAND, 1994

An integral part of the U.S. Geological Survey's mission is to conduct investigations of the Nation's land, mineral, and water resources on a continuing, systematic, and scientific basis and to publish and disseminate the information needed to understand, plan the use of, and manage these resources. As the Nation's largest earthscience research agency, the U.S. Geological Survey (USGS) maintains a long tradition of providing accurate and impartial information to all. The Massachusetts-Rhode Island (MA-RI) District of the Water Resources Division of USGS, provides information on water resources of both States for the overall benefit of Massachusetts, Rhode Island, and the Nation. The activities of the Water Resources Division are divided into seven broad categories-

- Collection of hydrologic data

- Water-resources investigations and assessments

- Basic and problem-oriented hydrologic research

- Acquisition of information useful in predicting and delineating water-related natural hazards

- Coordination of Federal agencies in the acquisition of water data and the operation of water-information centers

- Scientific and technical assistance to State, local, and other Federal agencies, and to licenses of the Federal Energy Regulatory Commission in hydrologic studies

- Administration of the State Water Resources Research Institute and Grant Programs

A diverse group of water-resource professionals conducts these activities in cooperation with other agencies, universities, and environmental groups, and disseminates data and information in an unbiased manner. Data, interpretive findings, and research results are distributed through USGS reports and maps, cooperator reports, journal papers, national data files, conferences, news releases, among other outlets. To date, more than 200 reports have been published by the Water Resources Division of the USGS on various aspects of water resources in Massachusetts and Rhode Island.
A 100-person staff consisting of hydrologists, hydrologic technicians, students, volunteers, and other administrative and technical personnel performs diverse tasks in support of the District's varied programs. Among the technical disciplines represented by the District's staff are hydrology, engineering, geology, environmental science, chemistry, ecology, statistics, physics, mathematics, computer science, and cartography.

\section{ACTIVITIES AND PROGRAMS}

- Statewide streamflow networks, Mass. and R.I.

- Statewide low-flow streamflow network, Mass.

- Statewide ground-water level networks, Mass. and R.I.

- Surface-water quality network, R.I.

- Statewide water-use programs, Mass. and R.I.

- Evaluation of the effectiveness of highway-drainage systems in preventing salt contamination of ground water, Route 25 from Wareham to the Cape Cod Canal, Mass.

- Processes controlling transport of solutes in a sewage plume in ground water at Otis Air Force Base, Cape Cod, Mass.

- Ground water and low flows in the Sudbury, Assabet, and Concord River Basins, Mass.

- Effects of discharge from a septage-treatment plant on ground-water quality and nitrogen transformations in a developing septage plume in Orleans, Mass.

- Analysis of the effects of changing pumping and recharge rates on ground-water flow in the Cape Cod, Martha's Vineyard, and Nantucket Island basins, Mass.

- Screening for potential public water-supply areas using a geographic information system, Cape Cod, Mass.

- Stream-aquifer interactions and yields of stratified-drift aquifers in the Buzzards Bay Planning Basin, Mass.

- Development alternatives in the Usquepaug-Queen groundwater reservoir, R.I.

- Simulation of ground-water flow on the Massachusetts Military Reservation 
- Connecticut, Housatonic, and Thames River Basins National Water-Quality Assessment Program study

- Hydrogeological technical assistance to the U.S. Environmental Protection Agency, Waste Management Division, Region I, at Superfund sites and Federal facilities

- Assessment and evaluation of stream stability and scour at bridges in Mass.

- Ground-water resources of the Deerfield River Basin, Mass.

- Technical assistance to the U.S. Army, Ft. Devens Installation Restoration Program, Mass.

- Fate of a plume of wastewater in a coastal marsh, Orleans, Mass.

- Ground-water and surface-water resources of the Tenmile River Basin, Mass.

- Transport of phosphorus to Ashumet Pond, Cape Cod, Mass.

- The role of organic material in biogeochemical control of dissolved-trace-metal toxicities and concentrations in New England streams

- Low-flow characteristics of streams in selected watersupply basins, R.I.

- Methods and guidelines for determining low-flow duration discharges in Mass.

- Ground-water discharge and recharge, and sediment transport in the Housatonic River Basin, Mass.

- Mercury transport and transformations on the Sudbury River, Mass., downstream from the Nyanza Superfund site

- Characterization of bedrock fractures at a ground-water contamination site using borehole and surface geophysical methods, Millville and Uxbridge, Mass.

\section{COOPERATING AGENCIES:}

\section{CITIES and TOWNS:}

Town of Burlington, Mass.

Town of New Shoreham, R.I.

\section{COUNTIES:}

Berkshire County, Mass.

Cape Cod Commission, Mass.

\section{UNIVERSITIES:}

University of Rhode Island

\section{STATE AGENCIES:}

Massachusetts Department of Environmental Management, Division of Resource Conservation
Massachusetts Department of Environmental Protection,

Office of Watershed Management

Division of Water Pollution Control

Division of Water Supply

Bureau of Waste Site Cleanup

Massachusetts Metropolitan District Commission

Division of Watershed Management

Parks, Engineering, and Construction Division

Massachusetts Water Resources Authority

Massachusetts Highway Department Bureau of Transportation, Planning, and Development Highway Engineering-Bridge Section

Rhode Island Department of Environmental Management Division of Water Resources

Division of Water Supply Management

Division of Ground Water and ISDS

Rhode Island Water Resources Board

Narragansett Bay Commission

FEDERAL AGENCIES:

U.S. Environmental Protection Agency, Region I Waste Management Division

U.S. Army Corps of Engineers

National Guard Bureau

U.S. Army

Federal Energy Regulatory Commission

\section{OTHER AGENCIES:}

Dedham-Westwood Water District

New England Interstate Water Pollution Control Commission

Providence Water Supply Board, R.I.

FOR MORE INFORMATION, CONTACT:

District Chief, or Information Officer U.S. Geological Survey 28 Lord Road. Suite 280 Marlborough, Mass. 01752 (508) 485-6360 (508) 490-5068 FAX

Subdistrict Chief U.S. Geological Survey 275 Promenade Street, Suite 150 Providence. R.I. 02908 (401) 331-9050 (401) 331 -9062 FAX

Open-File Report 94-115 